\title{
First evidence of established populations of the taiga tick Ixodes persulcatus (Acari: Ixodidae) in Sweden
}

\author{
Thomas G. T. Jaenson 1* , Kairi Värv², Isabella Fröjdman ${ }^{3}$, Anu Jääskeläinen ${ }^{4}$, Kaj Rundgren ${ }^{5}$, Veerle Versteirt ${ }^{6}$, \\ Agustín Estrada-Peña ${ }^{7}$, Jolyon M. Medlock ${ }^{8,9}$ and Irina Golovljova ${ }^{2}$
}

\begin{abstract}
Background: The tick species Ixodes ricinus and I. persulcatus are of exceptional medical importance in the western and eastern parts, respectively, of the Palaearctic region. In Russia and Finland the range of I. persulcatus has recently increased. In Finland the first records of I. persulcatus are from 2004. The apparent expansion of its range in Finland prompted us to investigate if $I$. persulcatus also occurs in Sweden.

Methods: Dog owners and hunters in the coastal areas of northern Sweden provided information about localities where ticks could be present. In May-August 2015 we used the cloth-dragging method in 36 localities potentially harbouring ticks in the Bothnian Bay area, province Norrbotten (NB) of northern Sweden. Further to the south in the provinces Västerbotten (VB) and Uppland (UP) eight localities were similarly investigated.

Results: Ixodes persulcatus was detected in 9 of 36 field localities in the Bothnian Bay area. Nymphs, adult males and adult females ( $n=46$ ticks) of I. persulcatus were present mainly in Alnus incana - Sorbus aucuparia - Picea abies - Pinus sylvestris vegetation communities on islands in the Bothnian Bay. Some of these I. persulcatus populations seem to be the most northerly populations so far recorded of this species. Dog owners asserted that their dogs became tick-infested on these islands for the first time 7-8 years ago. Moose (Alces alces), hares (Lepus timidus), domestic dogs (Canis lupus familiaris) and ground-feeding birds are the most likely carriers dispersing I. persulcatus in this area. All ticks $(n=124)$ from the more southern provinces of VB and UP were identified as I. ricinus.
\end{abstract}

Conclusions: The geographical range of the taiga tick has recently expanded into northern Sweden. Increased information about prophylactic, anti-tick measures should be directed to people living in or visiting the coastal areas and islands of the Baltic Bay.

Keywords: Ixodes persulcatus, Ixodes ricinus, Taiga tick, Geographical distribution, Sweden, Bothnian Bay, Norrbotten, Moose, Alces alces, Tick-borne pathogens

\section{Background}

Two closely related tick species are of particular medical importance as vectors of zoonotic viruses, bacteria and protists in the Palaearctic region: the castor bean tick Ixodes ricinus in Europe and the taiga tick I. persulcatus in eastern Europe and northern Asia [1-3]. Ixodes persulcatus is the main vector of the Siberian and Far

\footnotetext{
* Correspondence: Thomas.Jaenson@ebc.uu.se

${ }^{1}$ Medical Entomology Unit, Department of Organismal Biology, Evolutionary Biology Centre, Uppsala University, Norbyvägen 18d, SE-752 36 Uppsala, Sweden

Full list of author information is available at the end of the article
}

Eastern subtypes of the tick-borne encephalitis virus (TBEV) in northern Asia and eastern Europe [4, 5]. In some localities in its western range I. persulcatus is also a vector of the European subtype of TBEV [4, 6-8] the usual vector of which is I. ricinus. However, in a few localities (in Estonia, western Russia and south-eastern Finland) even I. ricinus may transmit the Siberian subtype [8,9]. Several other zoonotic pathogens have been detected in I. persulcatus, e.g. Powassan virus [4], Kemerovo virus [2, 6], Borrelia miyamotoi, B. afzelii, B. garinii, B. bavariensis, $B$. valaisiana [10], Anaplasma phagocytophilum [11, 12], Ehrlichia spp. [13], Candidatus Neoehrlichia mikurensis 
[12], Bartonella spp. [14], Rickettsia helvetica and other Rickettsia species [15], Babesia microti [16], Ba. venatorum [12] and $\mathrm{Ba}$. divergens [17]. In contrast to I. ricinus, which is more often found attached as nymphs than as adult females to people, it is nearly always the adult $I$. persulcatus female, which acts as the vector of pathogens to humans $[2,18]$.

The geographical distribution of $I$. persulcatus ranges from a scattered distribution in Finland, to a more continuous distribution from eastern Latvia and eastern Estonia through the taiga zone of European and Asian Russia into Mongolia and the Peoples Republic of China, Taiwan and North Korea eastwards to Hokkaido and Honshu in Japan [8, 18-21]. Ixodes persulcatus usually inhabits mixed deciduous-coniferous forest $[19,22]$.

In several regions of Russia $I$. persulcatus has recently increased its range and abundance, in particular towards the north [23-26]. In Finland, I. persulcatus was first recorded in the Kokkola archipelago on the west coast of Finland in 2004 [27] and in Närpiö (Närpes) in 2008 [28]. In the Kokkola archipelago I. persulcatus transmits the Siberian subtype of the TBE virus [27]. In 2008 and 2009 four human TBE cases were reported further to the north, i.e. from Simo $\left(65^{\circ} 40^{\prime} \mathrm{N}, 24^{\circ} 54^{\prime} \mathrm{E}\right)$ in Finnish Lapland [29]. Remarkably, the TBEV vector at Simo is $I$. persulcatus but here it transmits the European subtype of TBEV [29]. Thereafter, I. persulcatus was collected in Muhos in north-central Finland in May 2015 (Anu Jääskeläinen, unpublished observations) and in eastern Finland in Mekrijärvi and Kuhmo in 2008 and 2009 [30]. Based on ticks sent by the general public to the University of Turku (Åbo) in 2015, I. persulcatus seems now to have a wider distribution in Finland [31]. Immature ticks originating from the $I$. persulcatus populations in the Baltic region, Finland and European Russia could act as sources for the northward and northwestward spread of I. persulcatus by e.g. spring-migrating birds into Sweden. Even birds and mammals moving westwards might disperse ticks from northern Russia and Finland into Sweden.

The aim of this investigation was to determine if $I$. persulcatus is present in northern Sweden (provinces of Norrbotten and Västerbotten) and if this tick species is also present further to the south in eastern Sweden (in the province of Uppland). This decision was based on the following facts: (i) it has been estimated that $\approx 7$ million ticks are carried into Sweden each spring by migratory birds [32]; (ii) many of these ticks could originate from the Baltic countries and Finland, where I. persulcatus is present [7, 8, 21]; (iii) in 1992 we found a nymph of $I$. persulcatus on a warbler captured on a small island near the coast of northern Sweden [33]; (iv) I. persulcatus has recently expanded its range in northern European Russia [23, 24] and Finland; (v) and because climate change is likely to increase the possibility for $I$. persulcatus to become established in northern Sweden [26, 34].

\section{Methods}

\section{Study areas and climate}

The main study locations are situated in the provinces of Norrbotten (NB) and Västerbotten (VB) in northern Sweden (Fig. 1). These provinces are to the east bordered by the the Bothnian Bay and the Gulf of Bothnia, respectively and belong to the middle boreal subzone [35]. Norrbotten is to the west bordered by the Swedish province Lappland, which together with Norbotten form the northernmost provinces of Sweden. This is a typical taiga region, strongly dominated by forests but also in part by mires. It reaches in altitude to about $300 \mathrm{~m}$ a.s.l. in Västerbotten and to 150-200 m a.s.l. in Norrbotten. In the Bothnian Bay area, where we found $I$. persulcatus at several localities, the length of the vegetation period is about $140-150$ days and the annual precipitation 600-700 $\mathrm{mm}$ [35]. The July mean temperature is $15-16{ }^{\circ} \mathrm{C}$ [35]. This district is characterised by many large and small water-courses, lakes, extensive pine and spruce forests, coasts formed from isostatic, continuous uplift of the landmass after the last Ice age, brackish sea water and $>6,000$ islands. The human population density is low compared with southern Sweden. Most inhabitants of the Bothnian Bay area reside in the coastal regions and the river valleys [36].

About $280 \mathrm{~km}$ to the southwest of the Bothnian Bay area, four localities in the Norrbyskär archipelago, VB were investigated. Here, the length of the vegetation period is on average 150-160 days and the annual mean precipitation 700-800 $\mathrm{mm}$ [35]. Further to the south in the Swedish province Uppland (UP) located in the boreonemoral zone, four localities were investigated (Additional file 1: Table S1). Here, the mean duration of the growing season is 180-190 days [35].

\section{Tick collection localities}

We contacted dog owners and hunters living in the coastal areas of the province of Norbotten of northern Sweden and asked if they and/or their dogs had become infested by ticks in the Baltic Bay area. We then asked for the name(s) of the presumed locality/localities where any tick infestation had occurred. Based on this information we searched for ticks at a total of 36 localities in the Bothnian Bay area, NB during early May and in July and August 2015.

In addition, we searched for ticks further to the south in Sweden, in the provinces of Västerbotten (four localities) and Uppland (four localities) during August-October 2015. More information about each sampling locality is provided in Additional file 1: Table S1.

\section{Tick collection}

Sampling for ticks by the cloth-dragging method took place once at each of 44 localities during May - October 

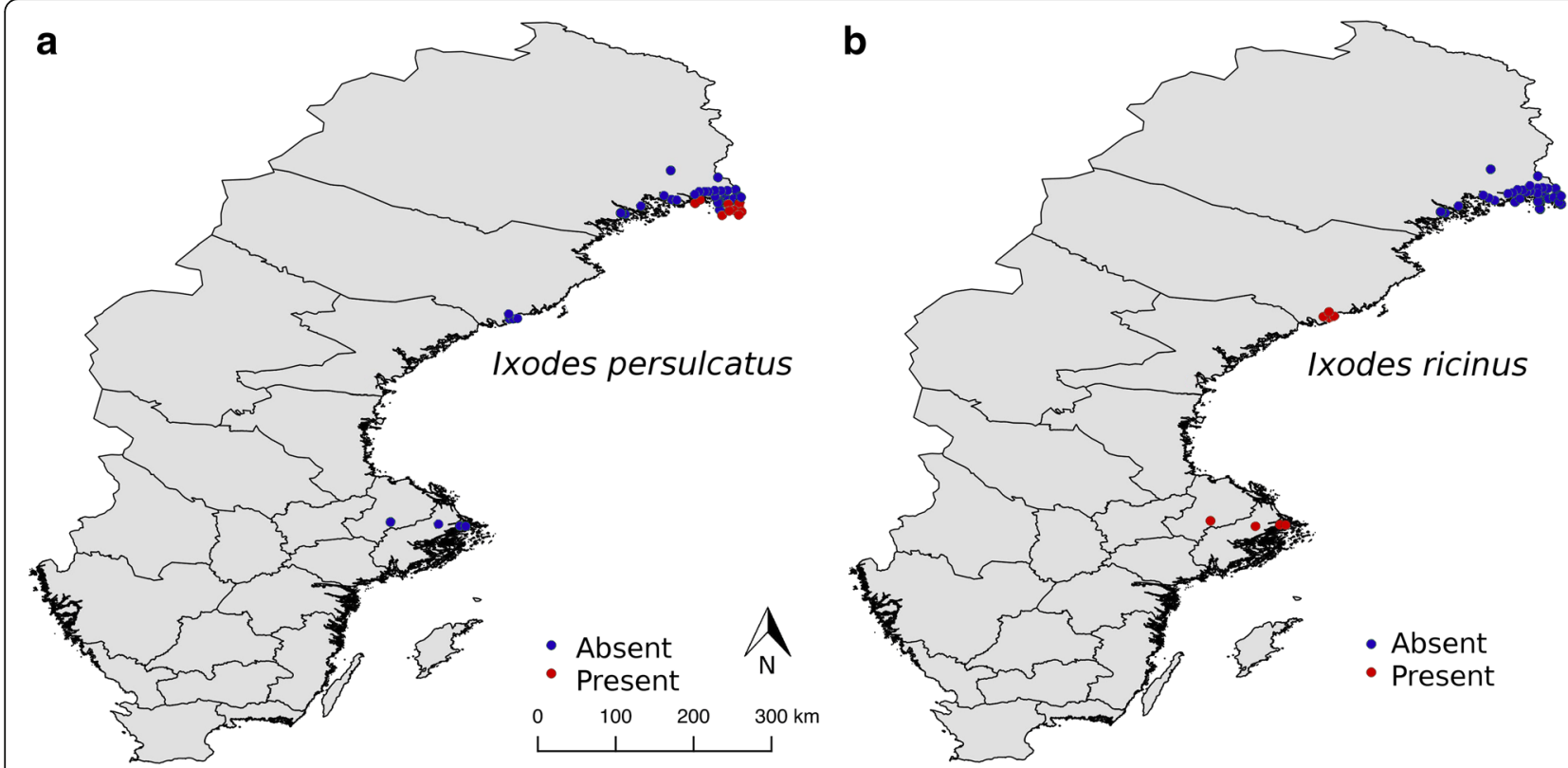

Fig. 1 a Map of Sweden showing localities where Ixodes persulcatus (filled red circles) was collected in 2015. Filled blue circles indicate localities where I. persulcatus was not recorded; b Map of Sweden showing localities where the tick I. ricinus (filled red circles) was collected in 2015. Filled blue circles indicate localities where I. ricinus was not recorded

2015 (Additional file 1: Table S1). All sampling sessions took place during daytime when the ground vegetation was not wet. A woollen $1 \mathrm{~m}^{2}$ cloth was pulled at slow walking pace over the ground vegetation and/or field vegetation for a total of $300 \mathrm{~m}$. At every $10 \mathrm{~m}$ of dragging both sides of the cloth were inspected with the help of a magnifying lens. Any tick detected was put in a numbered plastic vial containing $80 \%$ ethanol. If no tick had been collected after 30 stops $\left(300 \mathrm{~m}^{2}\right.$ of blanketdragging) another dragging-round of 30 stops $\left(300 \mathrm{~m}^{2}\right)$ was performed. At each sampling occasion the following parameters were recorded: time of the day, weather conditions, composition of the plant community and observation of mammal species and signs of their presence, temperature and relative humidity measured at ground level before and after each sampling period, and the location (longitude and latitude) of each sampling site (Additional file 1: Table S1).

\section{Tick identification}

All tick specimens were identified to stage and species by morphological characteristics. A Leitz Wild M10 stereomicroscope with possibility of magnifications up to $\times 200$ was used together with keys and illustrations in Filippova [3] and Yamaguti et al. [19]. By these means the unfed nymphs, adult females and adult males (Additional file 3: Figure S1) of I. persulcatus could be distinguished from the closely related $I$. ricinus. To further confirm the species diagnoses the morphology of the ticks collected in the Baltic Bay area was compared with that of ethanol- preserved I. persulcatus nymphs and adult male and female ticks collected in several Russian regions (St. Petersburg, Permsk, Khabarovsk, Sakhalin). The key (Additional file 2: Table S2) provides morphological characteristics, partly compiled from $[3,19]$, which were used to distinguish $I$. persulcatus from I. ricinus.

\section{Molecular tick species identification}

In order to check the species diagnoses based on morphological characteristics (Additional file 2: Table S2) we performed molecular species identification (see below) of 10 specimens morphologically identified as "I. persulcatus" from Norrbotten ( 9 females, 1 nymph) and 11 specimens morphologically identified as "I. ricinus" from Västerbotten (4 females, 3 nymphs) or Uppland (1 female, 3 nymphs).

Collected ticks were homogenized individually with Mixer Mill MM301 bead-milling system (Retsch GmbH, Haan, Germany) in $300 \mu$ l of sterile phosphate-buffered saline (PBS). Nucleic acid extraction was performed with guanidinium-phenol-chloroform method (TriPure Isolation system, Roche Diagnostics) according to manufacturer's instructions from $200 \mu \mathrm{l}$ of tick suspension. Sterile water was included as a negative control in every preparation set. The extracted DNA and RNA were stored at $-20{ }^{\circ} \mathrm{C}$ and $-70{ }^{\circ} \mathrm{C}$, respectively, prior to use.

Mitochondrial partial 16S rRNA gene was used as a marker for the identification of tick species using primers $16 \mathrm{Sa}$ and $16 \mathrm{Sb}$, as previously described [37]. The reaction was performed in a total volume of $25 \mu \mathrm{l}$, 
and the reaction mixture included $10 \times$ PCR buffer (Dream Taq, Thermo Scientific, Waltham, USA), per $1.5 \mathrm{mM}$ of $\mathrm{MgCl}_{2}$ and $1.5 \mathrm{mM}$ dNTPs (Thermo Scientific, Walthan, USA), $0.5 \mu \mathrm{M}$ of each primer and $2.5 \mathrm{U}$ of DreamTaq polymerase (Thermo Scientific, Waltham, USA). Cycling conditions were as follows: $95{ }^{\circ} \mathrm{C}$ for $1 \mathrm{~min} ; 49^{\circ} \mathrm{C}$ for $1 \mathrm{~min} ; 72^{\circ} \mathrm{C}$ for $2 \mathrm{~min} ; 95^{\circ} \mathrm{C}$ for $1 \mathrm{~min}$; $47{ }^{\circ} \mathrm{C}$ for $1 \mathrm{~min} ; 72^{\circ} \mathrm{C}$ for $2 \mathrm{~min}$; followed by 40 cycles of $95{ }^{\circ} \mathrm{C}$ for $30 \mathrm{~s}, 45^{\circ} \mathrm{C}$ for $1 \mathrm{~min}$ and $72{ }^{\circ} \mathrm{C}$ for $2 \mathrm{~min}$; and a final elongation step of $72{ }^{\circ} \mathrm{C}$ for $10 \mathrm{~min}$. PCR reactions were carried out on a ThermoCycler 2720 (Applied Biosystems, Thermo Fisher Scientific, Waltham, USA). All PCR products were sent for direct sequencing at the Estonian Biocentre (Tartu, Estonia). Obtained sequences were aligned and analyzed with BioEdit v. 7.0.9.0 software.

\section{Results}

Tick species in Norrbotten

A total of $46 \mathrm{I}$. persulcatus ticks (13 nymphs, 20 adult females and 13 adult males) was found in July and August at eight insular and one coastal locality in the Bothnian Bay area (Fig. 1a, Table 1; Additional file 1: Table S1). Ixodes ricinus was not found at any of the 36 localities surveyed in this area (Additional file 1: Table S1). This is the only area in Sweden where we have, so far, detected populations of $I$. persulcatus. The dominant plant community in which $I$. persulcatus was found can be classified as virgin mixed forest dominated by grey alder (Alnus incana), rowan (Sorbus aucuparia), Norway spruce (Picea abies) and Scots pine (Pinus sylvestris) (Additional file 4: Figure S2). Dog owners living at localities where we found I. persulcatus, informed us that "ticks began to infest their dogs 7-8 years ago". This suggests that the taiga tick became established in this area about ten years ago. Moreover, we received additional information of tick presence from people that they and/or their dogs had become infested by ticks on the following islands: Seskarö, Haparanda Sandskär, Västra Knivskär, Östra Knivskär, Stora Hamnskär, Hanhinkari and Ytterstlandet.

\section{Tick species in Västerbotten}

Four separate islands in the Norrbyskär archipelago were surveyed for ticks in August 2015. All 78 specimens were identified morphologically as I. ricinus. Ixodes persulcatus was not found among ticks collected at Norrbyskär.

\section{Tick species in Uppland}

A total of 46 tick specimens, all identified morphologically as $I$. ricinus, was collected from the four sampling

Table 1 Localities in the province of Norrbotten, North Sweden where Ixodes persulcatus* was collected by cloth-dragging during July-August 2015. Additional information is available in Additional file 1: Table S1

\begin{tabular}{|c|c|c|c|c|c|c|}
\hline $\begin{array}{l}\text { Locality number, name } \\
\text { and vegetation type }\end{array}$ & $\begin{array}{l}\text { Potential main tick } \\
\text { reproduction tick }\end{array}$ & $\begin{array}{l}\text { Date of tick } \\
\text { collection in } 2015\end{array}$ & $\begin{array}{l}\text { No. of } \\
\text { nymphs }\end{array}$ & $\begin{array}{l}\text { No. of } \\
\text { females }\end{array}$ & $\begin{array}{l}\text { No. of } \\
\text { males }\end{array}$ & $\begin{array}{l}\text { Total no. of ticks } \\
\text { recorded on } 600 \mathrm{~m}^{2}\end{array}$ \\
\hline Västra Knivskär & moose ${ }^{a}$, hare ${ }^{b}$ & 14 July & 7 & 15 & 10 & 32 \\
\hline \multicolumn{7}{|l|}{ Virgin mixed forest } \\
\hline \multicolumn{7}{|l|}{ Ytterstlandet } \\
\hline Virgin mixed forest & moose $^{a}$, hare ${ }^{b}$ & 6 August & 0 & 1 & 1 & 2 \\
\hline \multicolumn{7}{|l|}{ Ytterstlandet } \\
\hline Juniperus heath & moose ${ }^{a}$, hare ${ }^{b}$ & 6 August & 3 & 0 & 0 & 3 \\
\hline \multicolumn{7}{|l|}{ Östra Knivskär } \\
\hline Virgin mixed forest & moose ${ }^{a}$, hare ${ }^{b}$ & 9 August & 0 & 1 & 0 & 1 \\
\hline \multicolumn{7}{|l|}{ Östra Knivskär } \\
\hline Virgin mixed forest & moose ${ }^{a}$, hare ${ }^{b}$ & 9 August & 1 & 0 & 0 & 1 \\
\hline \multicolumn{7}{|l|}{ Östra Knivskär } \\
\hline Virgin mixed forest & moose $^{a}$, hare ${ }^{b}$ & 9 August & 2 & 0 & 0 & 2 \\
\hline \multicolumn{7}{|l|}{ Stora Hamnskär } \\
\hline Virgin mixed forest & moose $^{a}$, hare ${ }^{b}$, dog $^{c}$ & 9 August & 0 & 1 & 1 & $2^{* *}$ \\
\hline \multicolumn{7}{|l|}{ Stora Hamnskär } \\
\hline Virgin mixed forest & moose $^{a}$, hare ${ }^{b}$, dog $^{c}$ & 9 August & 0 & 0 & 1 & 1 \\
\hline \multicolumn{7}{|l|}{ Axelsvik } \\
\hline Virgin mixed forest & moose $^{a}$ hare $^{b}$, roe deer $^{d}$ reindeer $^{e}$ & 11 August & 0 & 2 & 0 & 2 \\
\hline
\end{tabular}

*All specimens were identified as I. persulcatus by morphological features (Additional file 2: Table S2)

Ten specimens were also identified as $I$. persulcatus by molecular criteria

**Two specimens were collected from a dog resident on Stora Hamnskär

${ }^{a}$ Alces alces; ${ }^{\mathrm{b}}$ Lepus timidus; ${ }^{\mathrm{C} C a n i s}$ lupus familiaris; ${ }^{\mathrm{d}}$ Capreolus capreolus; ${ }^{\mathrm{e}}$ Rangifer tarandus 
sites in Uppland. Ixodes persulcatus was not found among ticks collected in Uppland.

\section{Molecular diagnosis of tick species}

The species identity of ten tick specimens morphologically identified as $I$. persulcatus from Norrbotten ( 9 females, 1 nymph) and 11 specimens morphologically identified as $I$. ricinus from Västerbotten (4 females, 3 nymphs) or Uppland ( 1 female, 3 nymphs) was verified by $16 \mathrm{~S}$ rRNA sequencing. In all cases molecular identification correlated positively with morphological species discrimination. The intraspecies similarity between obtained $16 \mathrm{~S}$ rRNA sequences was on average $98.7 \%$ and $99.9 \%$ for I. ricinus and I. persulcatus, respectively. Nine I. persulcatus ticks out of ten had identical 16S rRNA sequences; the remaining sequence differed by one nucleotide deletion at position 304 . Ixodes ricinus sequences demonstrated higher variability with similarity values ranging from $97.4 \%$ to $100 \%$ between samples. 16S rRNA sequences from Swedish I. ricinus and I. persulcatus ticks were aligned and compared to complete and partial 16S rRNA sequences available in the NCBI DNA database. Swedish I. ricinus sequences were highly similar or identical with previously published sequences from Germany (JF928527), France (GU074616), Slovakia (GU074590), Ireland (GU074595), Estonia (GU074594), and Lithuania (KT070766, KT070770, KT070778). Obtained I. persulcatus sequences were 99.6$100 \%$ identical with the following GenBank submissions: Japan, Aomori (AB819250), Russia (JF934741), Russia, East Siberia (KP866204) and Lithuania (KP283020).

\section{Discussion}

\section{The geographical expansion of Ixodes persulcatus}

Here we report the presence of $I$. persulcatus in the Province of Norrbotten, Bothnian Bay area, northern Sweden. Before this study there was only one previous record of I. persulcatus from Sweden: one nymph was removed from a willow warbler Phylloscopus trochilus captured on 19 May 1992 on the island of Stora Fjäderägg in the Bothnian Sea [33] about $100 \mathrm{~km}$ to the west of the Kokkola archipelago, Finland where I. persulcatus was discovered in 2004 [27].

Investigations show that the reproductive ranges of $I$. ricinus and $I$. persulcatus in northern Europe seem to have increased towards the north during the last few decades. This applies to I. ricinus in Norway $[38,39]$ and Sweden [40]. In Sweden I. ricinus has increased its abundance and geographical distribution northwards during the last two decades [33]. This tick species is now abundant in southern and south-central Sweden and along the Baltic Sea coast to about $64^{\circ} \mathrm{N}$. North of this latitude there have been many scattered records of I. ricinus since the 1980s [33].
In north-western European Russia I. persulcatus has extended its range and has also become more abundant [23, 24]. In Karelia, Bugmyrin and co-workers recorded a significantly increased abundance of $I$. persulcatus and a decrease in I. ricinus abundance since the 1950s [23]. Southern Karelia is presently a sympatric zone for I. ricinus and I. persulcatus [23]. In most of Karelia, except to the west of Lake Ladoga, I. persulcatus is now the most abundant of the two tick species [23]. In the Archangelsk region, Tokarevich and co-workers recorded an increased abundance of $I$. persulcatus as well as a drastically increased incidence of human TBE [24]. This increased TBE incidence is considered to be related to the increasing mean annual air temperature in that area [24]. Since I. persulcatus has recently extended its reproductive range towards the north and north-west in north-western Russia and in Finland, we may expect that the range of this tick species will soon become larger even in Sweden.

\section{Climatic requirements of $I$. persulcatus seem to differ from those of $I$. ricinus}

In the Bothnian Bay area, where we found I. persulcatus at several localities, and where permanent populations of I. ricinus appear not to exist, the mean length of the vegetation period is $140-150$ days [35]. We have previously shown that $I$. ricinus is commonly encountered in areas where the vegetation period is $>180$ days/year and is absent from areas with a vegetation period $<160$ days/ year [41]. An annual vegetation period of 170 days was found to have a good fit with the northern distribution limit of I. ricinus [41]. Another climate index, which like the vegetation period is dependent on the latitude and altitude above sea level, is the temperature sum $\left(T_{S}\right)$. This is the total daily mean temperature above $+5{ }^{\circ} \mathrm{C}$ during the vegetation period and is an index of how warm this season is. In the Bothnian Bay area $T_{S}=900-1,100$ daydegrees, at Norrbyskär $T_{S}=1,100-1,300$ day-degrees, and in the province of Uppland $\mathrm{T}_{\mathrm{S}}=1,300-1,500$ day-degrees [42]. Total mean precipitation during the growing season is for these three areas $250-300 \mathrm{~mm}, 250-300 \mathrm{~mm}$ and $300-450 \mathrm{~mm}$, respectively [42]. Another potentially relevant climate index is the humidity during the growing season. This climate index could be relevant in the study of small organisms like Ixodes ticks, which are sensitive to a high saturation deficit ( low humidity). In relation to other parts of Sweden the summers in eastern Sweden are, in general, relatively dry with little rainfall. And in fact, the Baltic Bay area, the Norrbyskär archipelago, and the province of Uppland have an almost identical and quite low humidity index, i.e. minus $50-0$ during the vegetation period [42]. In view of the present findings of I. persulcatus in the Bothnian Bay region and the climatological data presented here we believe that I. persulcatus is able 
to live and reproduce in a region of North Sweden where the mean annual vegetation period duration is relatively very short or approximately 140-150 days. We suspect that the length of this period is here too short for $I$. ricinus. The reason may be that the temperature sum is too low. In other words, the summers in this northerly area are too cold and do not provide sufficient energy to permit permanent reproducing populations of I. ricinus to survive in the Baltic Bay area.

\section{What is the origin of the I. persulcatus ticks in the Baltic Bay area?}

The main hosts of the adult I. persulcatus ticks are wild ungulates, particularly roe deer (Capreolus capreolus), red deer (Cervus elaphus), European moose (Alces alces), reindeer (Rangifer tarandus) and hares (Lepus spp.) [18, 19, 22]. The nymphs feed on many species of ground-feeding birds, small mammals and hares, squirrels and hedgehogs. The larvae rarely attack large mammals but feed mainly on small mammals and ground-feeding birds [18, 22]. As moose and the varying hare (L. timidus) are the most abundant medium-sized to large mammals on the islands where we found I. persulcatus it is likely that these mammals are the most important maintenance hosts (reproduction host) for this tick species in this area. It is presumably also the moose, the varying hare and domestic dog together with ground-feeding birds, which disseminate I. persulcatus to previously uninfested islands and coastal localities.

Reindeer (Rangifer tarandus) is another abundant, potential tick-disseminator in this area. Like moose and hares, reindeer is an excellent swimmer and can, in summer and early autumn swim between islands in the Baltic Bay archipelago. However, to control infestations by larvae of the reindeer warble fly (Oedemagena tarandi) and the reindeer throat botfly (Cephenemyia trompe), most of these semi-domesticated cervids are treated once a year with ivermectin or doramectin [43]. These drugs are effective for controlling the myiasis-causing oestrid flies mentioned, but are also used against parasitic nematodes and ectoparasitic arthropods, e.g. mites and ticks [43]. This may imply that in areas of northern Fennoscandia where reindeer are usually treated with any of these substances, such reindeer would presumably have a negative impact on the fecundity and potential vectorial capacity of $I$. persulcatus.

The populations of $I$. persulcatus now established on islands in the Baltic Bay area most likely originated from populations that have recently been detected on islands and along the coast of western and north-western Finland. Ground-feeding migratory birds are important for both short and long distance distribution of ticks. Moose, reindeer, hares, domestic dogs and other mammals could also be responsible for the spread of $I$. persulcatus. In contrast to most birds, large and medium- sized mammals are often infested by adult ticks. Such mammals, rather than small birds, could therefore be a more effective way of transporting potentially reproducing ticks, which could become effective founders of new I. persulcatus populations.

\section{Transmission of pathogens by I. persulcatus}

Ixodes persulcatus is one of the most important vectors of human-pathogenic viruses and microorganisms in the temperate area of the Palaearctic region. Some of the pathogens vectored by this tick species may cause serious disease and even death in humans. Prior to the discovery of $I$. persulcatus in Finland I. ricinus was the only known vector of TBEV in Finland. Most human TBE cases were reported from the Aland archipelago in the Baltic Sea. These TBE cases were all considered to have been caused by the western subtype of the TBE virus [44]. In view of the TBEV focus at Simo [29] in northwestern Finland, less than $100 \mathrm{~km}$ from some of the Swedish islands infested by $I$. persulcatus, it is likely that the TBE virus is already present or will soon be present in the Swedish I. persulcatus populations. Introduction of the TBE virus to new localities where a potential vector exists may occur in several ways, such as: (i) with infected birds; (ii) with infected small or medium-sized mammals; (iii) with infected ticks attached to migratory birds; (iv) and/or with infected ticks attached to migrating cervids such as a moose and roe deer. All factors required for the establishment of one or more TBEV foci seem to be present in the Bothnian Bay area. A competent vector, $I$. persulcatus, is present in several localities. In most or all localities in the Baltic Bay area infested by I. persulcatus, moose is abundant and thus available as feeding and mating sites for the adult ticks. Several species of small and medium-sized mammals are competent TBEV transmission hosts [45]. Among such species present in the Bothnian Bay area are: Myodes glareolus, Microtus agrestis, Sciurus vulgaris and Sorex araneus [46]. One or more of these small mammal species are also proven competent reservoirs and transmission hosts for Borrelia afzelii [10], B. miyamotoi [47] and other pathogens vectored by $I$. persulcatus. Thus, if $I$. persulcatus extends its range in Sweden and becomes more abundant there, human diseases caused by the different subtypes of TBEV, Lyme borrelioses due to B. afzelii, $B$. garinii and other $B$. burgdorferi(sensu lato) genospecies, relapsing fever caused by $B$. miyamotoi, and certain rickettsioses and babesioses may become more common in people living in northern Sweden.

\section{Conclusions}

This study showed that the geographical range of the taiga tick $I$. persulcatus has recently expanded into northern Sweden. In view of the extraordinary importance of this 
tick species as a vector of several pathogens of humans, domesticated mammals and livestock information via mass media and by other means about prophylactic, antitick measures should be directed to people living in or visiting the coastal areas and islands of the Baltic Bay. Surveillance to detect the potential presence of the taiga tick elsewhere in Sweden has been initiated.

\section{Additional files}

Additional file 1: Table S1. Description of the localities investigated for possible occurrence of Ixodes ticks. (DOCX $68 \mathrm{~kb}$ )

Additionla file 2: Table S2. Morphological characteristics distinguishing 1. persulcatus from I. ricinus based on [3, 19]. (DOCX $22 \mathrm{~kb})$

Additional file 3: Figure S1. Ixodes persulcatus collected on islands in the Bothnian Bay, northern Sweden in July 2015. Top row from left to right: dorsal view of nymph, adult female and adult male. Bottom row from left to right: ventral view of nymph, adult female and adult male. (TIF $32566 \mathrm{~kb}$ )

Additional file 4: Figure S2. Biotopes inhabited by the taiga tick, Ixodes persulcatus and moose, Alces alces in the Bothnian Bay archipelago, northern Sweden a. Mixed birch - spruce - rowan - willow and blueberry vegetation community on the island of Östra Knivskär, Haparanda municipality, 9th August 2015. b. Mixed birch - willow - grey alder woodland with field layer of bracken. Östra Knivskär, Haparanda municipality, 9th August 2015. c. Land upheaval mixed forest of grey alder, spruce, rowan, willow and Scots pine. Stora Hamnskär, Haparanda municipality, 9th August 2015. d. Mixed birch, spruce, rowan, pine and grey alder vegetation. Axelsvik, Kalix municipality, 11th August 2015. (TIF $38889 \mathrm{~kb}$ )

\section{Abbreviations}

a.s.l., above sea-level; NB, Province of Norrbotten, Sweden; NCBI, National Center for Biotechnology Information; PBS, phosphate-buffered saline; TBEV, tick-borne encephalitis virus; $T_{5}$. temperature sum; UP, Province of Uppland, Sweden; VB, Province of Västerbotten, Sweden

\section{Acknowledgements}

For information about the potential occurrence of ticks in certain localities we are indebted to Torbjörn Forsberg, Nysätra; Stig Olof Lövgren, Påläng (Kalix); Gunnar Eriksson, Kalix-Nyborg; Lisbeth Pantzare, Haparanda; Lennart Johansson, Renholmen, Piteå; Tommy Westin, Seskarö; Maria Brattsand, Umeå; Staffan and Ida Svanberg, Haparanda; Erkki and Eine Partanen, Haparanda; Allan Bergström, Måttsund, Luleå; Tore, Ann-Marie, Niklas and Alfred Wikström, Ytterstlandet; Jens and Anneli Nilsson, Ytterstlandet; Ellinor Rönnkvist, Vitgrundet; Kjell Strömbäck, Lutskärsgrundet and Jan Morin, Lägenön who all provided information of particular value to this project. We are grateful to all people who collected and sent to us ticks for species identification, particularly Maria Brattsand, Umeå and staff members of the Veterinary clinics in Sundsvall: Berguven; Veterinärhuset, and Sundsvalls veterinärmottagning AB. TGTJ is indebted to Ivanka Kostova, Uppsala for translation into Swedish of numerous Russian texts, to Hans Mejlon, Uppsala University for skilful microphotography of ticks, to David Jaenson, Faculty of Engineering, Lund University and Mikael Fahlander, Uppsala University for expert IT assistance, and to Gustav Ydén, KFUM, Umeå for helpful logistic support at Norrbyskär. We are indebted to Guy Hendrickx and the staff members of Avia-GIS for invaluable intellectual and logistic support, and to Wim van Bortel, ECDC for helpful suggestions on an initial version of the manuscript. This work was carried out under the auspices of ESGBOR (the European Study Group on Lyme Borrelioses) and VectorNet, a European network for sharing data on the geographic distribution of arthropod vectors, transmitting human and animal disease agents (framework contract OC/EFSA/AHAW/2013/ 02-FWC1) funded by the European Food Safety Authority (EFSA) and the European Centre for Disease prevention and Control (ECDC).

\section{Funding}

TGTJ's research on the ecology of ticks and tick-borne infections is funded by Carl Trygger's stiftelse, Helge Ax:son Johnson's stiftelse, Längmanska kulturfonden and Magnus Bergvall's stiftelse, all in Stockholm, Sweden. This work was carried out under the auspices of ESGBOR (the European Study Group on Lyme Borrelioses) and VectorNet, a European network for sharing data on the geographic distribution of arthropod vectors, transmitting human and animal disease agents (framework contract OC/EFSA/AHAW/2013/02-FWC1) funded by the European Food Safety Authority (EFSA) and the European Centre for Disease prevention and Control (ECDC).

\section{Availability of data and materials}

Data and other information supporting the results are presented in Table 1 and Fig. 1 and in the Additional file 1: Tables S1, Additional file 2: Table S2, Additional file 3: Figure S1 and Additional file 4: Figure S2. Additional information can be obtained at request from the corresponding author. Representative sequences were deposited in the GenBank database under numbers from KX384801 to KX384812.

\section{Authors' contributions}

W, JM and AEP initiated this investigation. TGTJ in collaboration with JM and W directed the investigation. TGTJ compiled, analysed and synthesised published and unpublished information on the subject and wrote the initial and final versions of the manuscript. All ticks listed in Additional file 1: Table S1 were identified to species by TGTJ. IF and TGTJ visited nearly all tick collection localities and collected nearly all ticks listed in Additional file 1: Table S1. KV under the supervision of IG carried out the molecular identification of the ticks and wrote the corresponding text sections. AJ provided important information on I. persulcatus in Finland. KR played a decisive role in finding the first Swedish localities harbouring I. persulcatus and provided important information about the treatment of reindeer with ivermectin. All authors contributed significantly to the analyses and discussions on tick ecology and epidemiology of tick-borne infections. All co-authors co-revised the manuscript. All authors read and approved the final version of the manuscript.

\section{Competing interests}

The authors declare that they have no competing interests.

\section{Consent for publication}

Not applicable. This research does not contain any individual person's data.

Ethics approval and consent to participate

Not applicable. This paper does not report on and does not involve the use of any animal or human data or tissue.

\section{Author details}

Medical Entomology Unit, Department of Organismal Biology, Evolutionary Biology Centre, Uppsala University, Norbyvägen 18d, SE-752 36 Uppsala, Sweden. ${ }^{2}$ Department of Virology, National Institute for Health Development, Hiiu 42, 11619 Tallinn, Estonia. ${ }^{3}$ Aalto University, P.O. Box 11130 FI-00076 Aalto, Finland. ${ }^{4}$ Department of Virology, University of Helsinki, P.O. Box 21FI-00014 Helsinki, Finland. ${ }^{5}$ Järvis väg 50, SE-953 95 Nikkala, Sweden. ${ }^{6}$ Precision Pest Management Unit, Avia-GIS, Risschotlei 33, BE-2980 Zoersel, Belgium. 7 Department of Parasitology, University of Zaragoza, Miguel Servet 177, ES-50013 Zaragoza, Spain. ${ }^{8}$ Medical Entomology Group, Emergency Response Department, Public Health England, Porton Down, Salisbury, UK. ${ }^{9}$ Health Protection Research Unit in Emerging Infections and Zoonoses, Porton Down, Salisbury, UK.

Received: 4 February 2016 Accepted: 20 June 2016 Published online: 01 July 2016

\section{References}

1. Filippova NA. Taiga Tick Ixodes persulcatus Schulze (Acarina, Ixodidae). Morphology, Systematics, Ecology, Medical Importance. Leningrad: Nauka; 1985 (In Russian).

2. Nicholson NL, Sonenshine DE, Lane RS, Uilenberg G. Ticks (Ixodida). In: Mullen GR, Durden LA, editors. Medical and veterinary entomology. 2nd ed. Amsterdam: Elsevier; 2009. p. 493-542. 
3. Filippova NA. Fauna SSSR Paukoobraznye. Ixodid ticks of the subfamily Ixodinae. Leningrad: Nauka; 1977.

4. Charrel RN, Attoui H, Butenko AM, Clegg JC, Deubel V, Frolova TV, et al. Tick-borne virus diseases of human interest in Europe. Clin Microbiol Infect. 2004;10(12):1040-55.

5. Zilber LA. Spring-summer tick-borne encephalitis. Arkhiv Biol Nauka. 1939;56: 255-61.

6. Labuda M, Nuttall PA. Tick-borne viruses. Parasitology. 2004;129(Suppl): S221-45.

7. Süss J. Tick-borne encephalitis 2010: Epidemiology, risk areas and virus strains in Europe and Asia. - An overview. Ticks Tick Borne Dis. 2011.2:2-15.

8. Katargina O, Russakova S, Geller J, Kondrusik M, Zajkowska J, Zygutiene M, et al. Detection and characterization of tick-borne encephalitis virus in Baltic countries and eastern Poland. PLoS One. 2013;8(5):e61374.

9. Jaaskelainen A, Tonteri E, Pieninkeroinen I, Sironen T, Voutilainen L, Kuusi M, et al. Siberian subtype tick-borne encephalitis virus in Ixodes ricinus in a newly emerged focus, Finland. Ticks Tick Borne Dise. 2016:7(1):216-23.

10. Franke J, Hildebrandt A, Dorn W. Exploring gaps in our knowledge on Lyme borreliosis spirochaetes - updates on complex heterogeneity, ecology, and pathogenicity. Ticks Tick Borne Dis. 2013;4(1-2):11-25.

11. Shpynov SN, Rudakov NV, lastrebov VK, Leonova GN, Khazova TG, Egorova NV, et al. [New evidence for the detection of Ehrlichia and Anaplasma in Ixodes ticks in Russia and Kazakhstan]. Med Parazitologiia Parazit Bolezni 2004;(2):10-14. (In Russian)

12. Karnath C, Obiegala A, Speck S, Essbauer S, Derschum H, Scholz H, et al. Detection of Babesia venatorum, Anaplasma phagocytophilum and Candidatus Neoehrlichia mikurensis in Ixodes persulcatus ticks from Mongolia. Ticks Tick Borne Dis. 2016;7(2):357-60.

13. Alekseev AN, Dubinina HV, Jushkova OV. First report on the coexistence and compatibility of seven tick-borne pathogens in unfed adult Ixodes persulcatus Schulze (Acarina: Ixodidae). Int J Med Microbiol. 2004;293 Suppl 37:104-8.

14. Rar VA, Fomenko NV, Dobrotvorsky AK, Livanova NN, Rudakova SA, Fedorov EG, et al. Tick-borne pathogen detection, Western Siberia, Russia. Emerg Infect Dis. 2005:11(11):1708-15.

15. Inokuma H, Ohashi M, Jilintai, Tanabe S, Miyahara K. Prevalence of tickborne Rickettsia and Ehrlichia in Ixodes persulcatus and Ixodes ovatus in Tokachi district, Eastern Hokkaido, Japan. J Vet Med Sci/Japanese Soc Vet Sci. 2007:69(6):661-4.

16. Alekseev AN, Semenov AV, Dubinina HV. Evidence of Babesia microti infection in multi-infected /xodes persulcatus ticks in Russia. Exp Appl Acarol. 2003;29(3-4):345-53.

17. Katargina O, Geller J, Vasilenko V, Kuznetsova T, Jarvekulg L, Vene S, et al. Detection and characterization of Babesia species in Ixodes ticks in Estonia. Vector Borne Zoonot Dis. 2011;11(7):923-8.

18. Korenberg El, Gorelova NB, Kovalevskii YI. Ecology of Borrelia burgdorferi sensu lato in Russia. In: Gray JS, Kahl O, Lane RS, Stanek G, editors. Lyme borreliosis Biology Epidemiology and Control. 1st ed. Oxon: CABI Publishing; 2002. p. 175-200.

19. Yamaguti N, Tipton, VJ, Keegan HL, Toshika S. Ticks of Japan, Korea, and the Ryuku Islands, Vol. XV. Provo, Utah, USA: Brigham Young University; 1971

20. Kolonin GV. Fauna of ixodid ticks of the world (Acari, Ixodidae). Moscow 2014. http://www.kolonin.org/.

21. Bormane A, Lucenko I, Duks A, Mavtchoutko V, Ranka R, Salmina K, Baumanis $V$. Vectors of tick-borne diseases and epidemiological situation in Latvia in 1993-2002. Int J Med Microbiol. 2004;293 Suppl 37:36-47.

22. Pomerantzev BI. Fauna of the USSR. Arachnida. Ixodid ticks (Ixodidae). Moscow: Zool Inst Acad Sci USSR; 1950

23. Bugmyrin SV, Bespyatova LA, Korotkov YS, Burenkova LA, Belova OA, Romanova $\mathrm{L}$, et al. Distribution of Ixodes ricinus and I. persulcatus ticks in southern Karelia (Russia). Ticks Tick Borne Dis. 2013;4(1-2):57-62.

24. Tokarevich NK, Tronin AA, Blinova OV, Buzinov RV, Boltenkov VP, Yurasova ED, Nurse J. The impact of climate change on the expansion of Ixodes persulcatus habitat and the incidence of tick-borne encephalitis in the north of European Russia. Global Health Act. 2011:4:8448.

25. Yasukevich W, Kazakova EV, Popov IO, Semenov SM. Distribution of Ixodes ricinus L., 1758 and Ixodes persulcatus Shulze, 1930 (Parasitiformes, Ixodidae) in Russia and adjacent countries in view of observable climate changes. Dokl Earth Sci. 2009;427A(6):1030-4

26. Uspensky I, Garruto RM, Goldfarb L. The taiga tick Ixodes persulcatus (Acari: Ixodidae) in the Sakha Republic (Yakutia) of Russia: distributional and reproductive ranges. J Med Entomol. 2003;40(1):119-22.
27. Jääskeläinen AE, Tikkakoski T, Uzcategui NY, Alekseev AN, Vaheri A, Vapalahti O. Siberian subtype tick-borne encephalitis virus, Finland. Emerg Infect Dis. 2006;12(10):1568-71.

28. Jääskeläinen $A E$, Sironen $T$, Murueva GB, Subbotina N, Alekseev AN, Castren J, et al. Tick-borne encephalitis virus in ticks in Finland, Russian Karelia and Buryatia. J Gen Virol. 2010;91(Pt 11):2706-12.

29. Jääskeläinen $A E$, Tonteri $E$, Sironen $T$, Pakarinen $L$, Vaheri $A$, Vapalahti $O$. European subtype tick-borne encephalitis virus in Ixodes persulcatus ticks. Emerg Infect Dis. 2011;17(2):323-5.

30. Bugmyrin S, Hokkanen TJ, Romanova L, Bespyatova L, Fyodorov F, Burenkova L, et al. Ixodes persulcatus [Schulze 1930] (Acari: Ixodidae) in eastern Finland. Entomol Fennica. 2011;22:268-73.

31. Ixodes ticks in SW Finland [http://www.utu.fi/en/units/sci/units/biology/ research/projects/Ixodes/Pages/home.aspx]

32. Olsen $B$, Jaenson TG, Bergstrom S. Prevalence of Borrelia burgdorferi sensu latoinfected ticks on migrating birds. Appl Environ Microbiol. 1995;61(8):3082-7.

33. Jaenson TG, Talleklint L, Lundqvist L, Olsen B, Chirico J, Mejlon H. Geographical distribution, host associations, and vector roles of ticks (Acari: Ixodidae, Argasidae) in Sweden. J Med Entomol. 1994;31(2):240-56.

34. Jaenson $\mathrm{TG}$, Lindgren $\mathrm{E}$. The range of Ixodes ricinus and the risk of contracting Lyme borreliosis will increase northwards when the vegetation period becomes longer. Ticks Tick Borne Dis. 2011;2(1):44-9.

35. Sjörs H. The Background: Geology, climate and zonation. In: Rydin H, Snoeijs P, Diekmann M, editors. Swedish Plant Geography. Vol. 84. Uppsala: Svenska Växtgeografiska Sällskapet; 1999. p. 5-14.

36. [http://www.lansstyrelsen.se/vasterbotten/Sv/miljo-och-klimat/tillstandet-imiljon/informationscentralen-for-bottniska-viken/Pages/default.aspx]

37. Caporale DA, Rich SM, Spielman A, Telford 3rd SR, Kocher TD. Discriminating between Ixodes ticks by means of mitochondrial DNA sequences. Mol Phylogenet Evol. 1995;4(4):361-5.

38. Jore $S$, Viljugrein $H$, Hofshagen M, Brun-Hansen $H$, Kristoffersen AB, Nygard $\mathrm{K}$, et al. Multi-source analysis reveals latitudinal and altitudinal shifts in range of Ixodes ricinus at its northern distribution limit. Parasit Vectors. 2011:4:84.

39. Hvidsten D, Stuen S, Jenkins A, Dienus O, Olsen RS, Kristiansen BE, et al. Ixodes ricinus and Borrelia prevalence at the Arctic Circle in Norway. Ticks Tick Borne Dis. 2014;5(2):107-12.

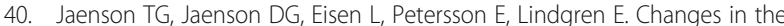
geographical distribution and abundance of the tick Ixodes ricinus during the past 30 years in Sweden. Parasit Vectors. 2012;5:8.

41. Jaenson TG, Eisen L, Comstedt P, Mejlon HA, Lindgren E, Bergstrom S, Olsen B. Risk indicators for the tick Ixodes ricinus and Borrelia burgdorferi sensu lato in Sweden. Med Vet Entomol. 2009;23(3):226-37.

42. Perttu K, Morén, A-S. Regionala klimatindex - verktyg vid bestämnintg av skogsproduktion [Regional Climate Index- tool in determining the forest production]. In: J. Elmberg MA, editor. Fakta Skog Sammanfattar aktuell forskning vid Sveriges Lantbruksuniversitet [Facts Forest Summarizes current research at the Swedish University of Agricultural Sciences]. SLU Info/Skog, 90183 Umeå, Sweden. Sveriges lantbruksuniversitet, SLU Info/Skog, Umeå: Swedish University of Agricultural Sciences, Uppsala, Sweden; 1995.

43. Josefsen TD, Oksanen A, Gjerde B. Parasittbehandling av rein. Norsk veterinærtidsskrift. 2014;126(2):216-9.

44. Jääskeläinen $\mathrm{A}$. Detection and molecular epidemiology of tick-borne encephalitis virus infections PhD. Helsinki University: Helsinki; 2011.

45. Hubalek Z, Rudolf I. Tick-borne viruses in Europe. Parasitol Res. 2012;111(1):9-36.

46. Bjärvall A, Ullström S. Däggdjur. Alla våra vilda arter i Sverige. Bonnier Fakta: Stockholm; 2010.

47. Burri C, Schumann O, Schumann C, Gern L. Are Apodemus spp. mice and Myodes glareolus reservoirs for Borrelia miyamotoi, Candidatus Neoehrlichia mikurensis, Rickettsia helvetica, R. monacensis and Anaplasma phagocytophilum? Ticks Tick Borne Dis. 2014;5(3):245-51. 